\title{
A Total Polyphenol Content of Mate (Ilex paraguariensis) and Other Plants-derived Beverages
}

\author{
Vanessa Graciela Hartwig ${ }^{1}$, Luis Alberto Brumovsky ${ }^{1} \&$ Maria Raquel Fretes $^{1}$ \\ ${ }^{1}$ Chemistry and Life Sciences, National University of Misiones, Posadas, Argentina \\ Correspondence: Vanessa Graciela Hartwig, School of Exact, Chemistry and Life Sciences, National University \\ of Misiones, Félix de Azara 1552, 3300-Posadas, Argentina. Tel: 54-037-6442-2186. E-mail: \\ vanesshart@yahoo.com.ar
}

Received: March 14, 2012 Accepted: April 1, 2012 Online Published: May 29, 2012

doi:10.5539/jfr.v1n3p58

URL: http://dx.doi.org/10.5539/jfr.v1n3p58

The research is financed by two organizations: National Council of Scientific and Technical Research (CONICET) and Mate's National Institute (INYM)

\begin{abstract}
The total polyphenol content (TPC) of three maté (Ilex paraguariensis St. Hil.) beverages under typical consumer conditions in Argentina: Hot Maté, Cold Maté and Maté tea-bag, were determined.TPC was measured by the Folin-Ciocalteu method and expressed as gallic and chlorogenic acid equivalents (GAE and CAE, respectively). In Hot Maté, the intake would be $5.15 \pm 0.55 \mathrm{~g} \mathrm{CAE} / 500 \mathrm{~mL}$ and $2.9 \pm 0.4 \mathrm{~g} \mathrm{GAE} / 500 \mathrm{~mL}$; in Cold Maté, the intake would be $1.9 \pm 0.4 \mathrm{~g} \mathrm{CAE} / 500 \mathrm{~mL}$ and $1.1 \pm 0.2 \mathrm{~g} \mathrm{GAE} / 500 \mathrm{~mL}$; one cup of Maté Tea-bag infusion $(200 \mathrm{~mL})$ contains between $0.55 \pm 0.05 \mathrm{~g} \mathrm{CAE}$ and $0.295 \pm 0.015 \mathrm{~g}$ GAE. Comparison of the TPC of several beverages provided evidence that beverages of maté are rich sources of antioxidant phenolics. Among several ways of consumption of maté, the Hot Maté provides the highest intake of total polyphenols.
\end{abstract}

Keywords: antioxidant, Folin-Ciocalteu, Ilex paraguariensis, maté beverages, polyphenols

\section{Introduction}

Yerba maté (Ilex paraguariensis St. Hil.) is a tree that grows in the central region of the MERCOSUR (Common Southern Market) countries (Paraguay, Brazil, Argentina and Uruguay); its leaves and twigs are processed to obtain two final products: elaborated maté and maté tea-bags. Elaborated maté is obtained through an industrial process that includes the following steps: heat treatment, drying, grinding and seasoning (Scipioni et al., 2010).

Maté products are consumed in the MERCOSUR region. In recent years, the USA and some countries in Europe and in the Middle East have begun to use maté infusion due to its antioxidant capacity (Heck et al., 2008). The maté is recognized worldwide for its nutritional and medicinal value being included in several nationals food codes such as the Argentine Food Code, Latin-American Food Code and Pharmacopoeias such as Martindale, British Herbal Pharmacopoeia and German Commission E Monographs (Anesini et al., 2006).

Several studies on maté have reported the presence of xanthines such as caffeine and theobromine, saponines, and several phenolic compounds, mainly chlorogenic acids and dicaffeoylquinic acid derivatives (Bravo et al., 2007; Dutra et al., 2010; González de Mejia et al., 2005; Heck et al., 2008; Jaiswal et al., 2010; Markowicz Bastos et al., 2007). It has also been reported that maté extracts have an in vitro antioxidant capacity (AOC) which is due to the presence of chlorogenic acids and dicaffeoylquinic acid derivatives that have an antioxidant capacity equal to or higher than that of ascorbic acid and vitamin E (Bravo et al., 2007; Chandra \& Gonzalez de Mejia, 2004). Dudonné et al. (2009) ranged aqueous extracts of mate in the fifth place of plants, among 30, with higher antioxidant activity.

Chandra and Gonzalez de Mejía (2004) reported a total polyphenol content (TPC) in the range from 9.0 to $17.6 \mathrm{~g}$ gallic acid equivalent (GAE) and from 23.6 to 49.0 chlorogenic acid equivalent (CAE) per $100 \mathrm{~g}$ of dry mass ( $\mathrm{dm}$ ) for maté beverages prepared as decoctions of nearly $3 \mathrm{~g}$ of mate leaves in $250 \mathrm{~mL}$ of boiling water.

Three different types of beverages are consumed. The Hot Maté is consumed in a special preparation, where 
$30-50 \mathrm{~g}$ of elaborated maté are placed in a gourd and fractions of approximately $30 \mathrm{~mL}$ of hot water (at 70 $85{ }^{\circ} \mathrm{C}$ ) are poured over solid repeatedly. The water is removed with a device similar to a straw, called "bombilla," that has a filter at one end (Scipioni et al., 2010). The Cold Maté, known as "tereré" is consumed in the same way that Hot maté but using cold water (at 5-8 ${ }^{\circ} \mathrm{C}$ ), and Maté Tea-bag, which is known as "maté cocido" and is prepared with the leaves only and brewed as any other herbal tea-bag.

Reports about TPC present in the three maté beverages mentioned above were not found in the literature. Their content will provide us an idea of the real intake of polyphenols by the consuming of maté beverages. The aim of the present research was to determine the TPC, as well as other physicochemical properties of these three maté beverages, and compare them with the TPC of other common beverages with well-known antioxidant properties such as red wine and the two major commercial tea products: green and black tea (Camellia sinensis) infusions.

\section{Materials and Methods}

\subsection{Reagents}

In total polyphenol content (TPC) determination, Folin-Ciocalteu's phenol reagent (Fluka, Argentina), chlorogenic acid (MP Biomedicals, Argentina), gallic acid (MP Biomedicals, Argentina), anhydrous sodium carbonate (99\% purity, Anedra, Argentina), methanol (Merck, HPLC grade, Argentina) and ethanol $96^{\circ}$, were used. In caffeine content determination, caffeine (Sigma Ultra, Argentina) and methanol (Merck, HPLC grade, Argentina) were used.

\subsection{Materials}

Samples of elaborated maté, maté tea-bag, red wine, and green and black tea (in tea-bags) were randomly purchased in local markets in Posadas, Misiones, Argentina. Ten different brands of elaborated maté, purchased in $1 \mathrm{~kg}$ paper bags, and five different brands of maté tea, purchased in boxes of 25 tea-bags each, were analysed. The contents of each package of elaborated maté were mixed by successive quartering before sampling. Each tea-bag used was randomly sampled. Five Argentinean brands of red wine (a Cabernet Sauvignon, a Malbec, a Syrah and two generics), six Argentinean brands of black tea and three Argentinean brands of green tea were analysed.

\subsection{Extractions}

Extractions were obtained simulating the way and proportions in which the beverages are usually prepared and consumed: for the Hot Maté, a glass recipient (diameter $=50 \mathrm{~mm}$ and height $=110 \mathrm{~mm}$ ) (Figure 1) was filled with $50 \pm 0.1 \mathrm{~g}$ of elaborated maté and a plastic straw was inserted in the material (Scipioni et al., 2010).

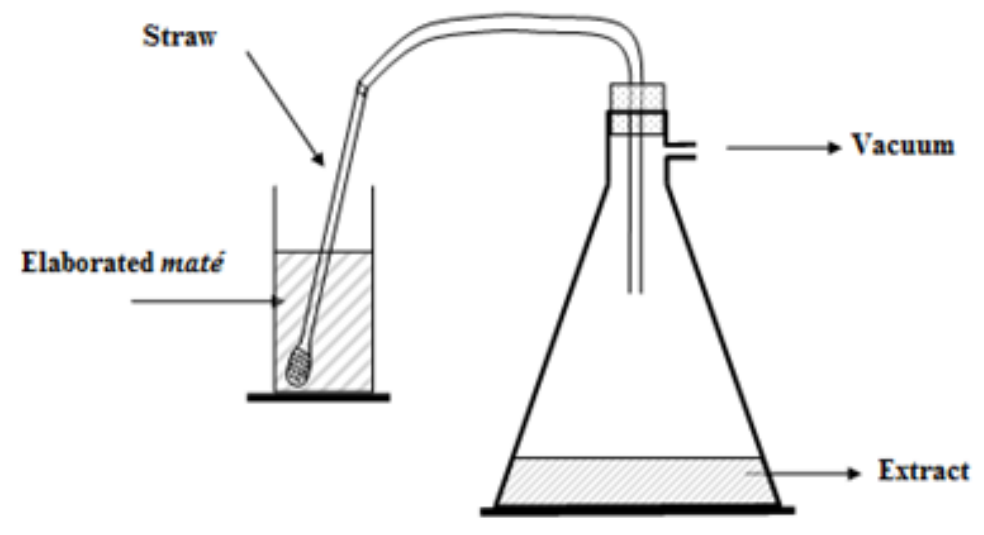

Figure 1. Device simulating the maté consumption

The submerged end of the straw had holes smaller than $0.8 \mathrm{~mm}$ that allowed the brewed liquid in, but blocked the solid powder. The straw was connected by a silicon hose to a kitasato flask, which was, in turn, connected to a vacuum pump. Then, approximately $20 \mathrm{~mL}$ of distilled water at $70^{\circ} \mathrm{C}$ was added, allowing the water to be absorbed into the maté for $20 \mathrm{~s}$. Vacuum was then applied for $20 \mathrm{~s}$ and when the vacuum stopped, the aliquot 
of hot water was added again. This process was repeated until the recovered volume in the kitasato flask reached $500 \mathrm{~mL}$. The preparation of Cold Maté was equal to that of the Hot Maté, except for the water temperature, which was $5{ }^{\circ} \mathrm{C}$. Maté Tea, black tea and green tea were prepared by brewing one commercial tea bag (net weight $=2-3 \mathrm{~g}$ ) in distilled boiling water, allowing it to brew for $5 \mathrm{~min}$. After this time, tea bags were removed and the final volume readjusted. Considering the tea bag charge varies considerably, in order to systematize the brewing procedure, the volume of boiling water used was according to a water/solid ratio of $67 / 1$.

As a control, the extraction method described by the international standard ISO 14502 was used for elaborated maté samples. This extraction method was also used in maté leaves and maté and twigs. Briefly, $0.200 \pm 0.001$ $\mathrm{g}$ of each sample was weighed in an extraction tube, and $5 \mathrm{~mL}$ of methanol $(70 \% \mathrm{v} / \mathrm{v})$ at $70{ }^{\circ} \mathrm{C}$ was added. The extract was mixed and heated at $70{ }^{\circ} \mathrm{C}$ on a vortex for $10 \mathrm{~min}$. After cooling at room temperature, the extract was centrifuged for $10 \mathrm{~min}$. The supernatant was decanted in a graduated tube. The extraction step was repeated twice. Both extracts were pooled and the volume adjusted to $10 \mathrm{~mL}$ with cold methanol $(70 \% \mathrm{v} / \mathrm{v})$.

\subsection{Moisture Content}

Water moisture was determined by the gravimetric method described by the standards IRAM 20503 (Argentinean standard, similar to standard ISO 1573 for tea samples). Briefly, around $2.500 \pm 0.001 \mathrm{~g}$ of sample was dried for $6 \mathrm{~h}$ at $103 \pm 2{ }^{\circ} \mathrm{C}$ in an oven. Results were expressed as mass percentage (g \% wet matter).

\subsection{Aqueous Extract}

The aqueous extract was obtained with boiling water under reflux under the conditions specified in the Argentinean standard IRAM 20510. The insoluble residue was then dried and weighed. Results were expressed as mass percentage ( $\mathrm{g}$ per $100 \mathrm{~g}$ of dry matter; or $\mathrm{g} \% \mathrm{dm}$ ).

\subsection{Total Soluble Solids}

An aliquot of $50 \mathrm{~mL}$ of each extract was fast paper-filtered and then $10 \mathrm{~mL}$ was transferred into a tared beaker and evaporated to dryness. The residue was dried for $16 \mathrm{~h}$ at $103 \pm 2{ }^{\circ} \mathrm{C}$ in an oven. Determinations were carried out in triplicate. Results were expressed as mass percentage (g per $100 \mathrm{~g}$ of dry matter; or g \% dm).

\subsection{Percentage of Each Fraction}

The percentage of leaves, twigs and impurities of mate samples were determined according to the Argentinean standard IRAM 20514. Each fraction was separated by sieving for 20 min using an electronic sieve. Determinations were carried out in triplicate. Results were expressed as mass percentage (g \%).

\subsection{Caffeine Content}

Caffeine was determined using an HPLC technique specified in the standard IRAM 20512. A C18 column (Ultrasphere; $250 \mathrm{~mm} \times 4.6 \mathrm{~mm}$, Beckman, USA) with a particle diameter of $5 \mu \mathrm{m}$, a mobile phase of methanol:water $(30: 70 \mathrm{v} / \mathrm{v})$ with a flux of $1.1 \mathrm{~mL} / \mathrm{min}$ were used, at $280 \mathrm{~nm}$ using a spectrophotometer UV/Vis (Waters, M481, spectrum bandwidth: $5 \mathrm{~nm}$ ). Determinations were carried out in duplicate. Results were expressed as mass percentage ( $\mathrm{g} \% \mathrm{dm})$.

\subsection{Total Polyphenol Content}

The total polyphenol content (TPC) was determined by a spectrophotometric technique, using a spectrophotometer UV/Vis (Spectrum SP-2102, photometric accuracy $0.3 \% \mathrm{~T}$, spectrum bandwidth: $2 \mathrm{~nm}$ ) according to the method described in the international standard ISO 14502. The content was expressed as gallic acid equivalents and chlorogenic acid equivalents in mass percentage of dry matter (GAE; CAE; g \% $\mathrm{dm}$ ). One milliliter of the diluted sample extract (or $1 \mathrm{~mL}$ of pure wine) was transferred in duplicate to separate tubes containing $5.0 \mathrm{~mL}$ of water diluted Folin-Ciocalteu's reagent $(10 \% \mathrm{v} / \mathrm{v})$. Then, $4.0 \mathrm{~mL}$ of a sodium carbonate solution $(7.5 \% \mathrm{w} / \mathrm{v})$ was added. The tubes were then allowed to stand at room temperature for $60 \mathrm{~min}$ before absorbance was measured at $765 \mathrm{~nm}$ against distilled water. The concentration of polyphenols in samples was derived from a standard curve of chlorogenic and gallic acid ranging from 0 to 60 $\mu \mathrm{g} / \mathrm{mL}\left(\mathrm{R}^{2}=0.997\right.$ and $\mathrm{R}^{2}=0.998$ respectively). The total polyphenol concentration in the original extracts (TPCo) was expressed as CAE and GAE in $\mu \mathrm{g} / \mathrm{mL}$ of the original extract. Determinations were carried out in duplicate.

\subsection{Statistics}

\subsubsection{Experiment Design}

The experiment was organized using a randomized complete block design, with each type of beverage as 
treatments (Hot Maté, Cold Maté and control extraction) and brands as blocks.

\subsubsection{Statistical Analysis}

Analysis of variance (ANOVA) was used. For comparing the TPC of Hot and Cold mate and control extractions, the Tukey's least significant difference was used. Correlation analysis was performed with the Pearson`s Correlation technique. All the comparisons were made at a $5 \%$ level of significance. Data are expressed as mean \pm standard error of two determinations per sample. All the statistical analysis were performed using Statgraphics Centurion XVI Académico.

\section{Results and Discussion}

\subsection{Results of Physicochemical Analysis}

In accordance with González de Mejía et al. (2005), the TPC of maté resulted higher when it is expressed as chlorogenic acid equivalents than when it is expressed as gallic acid equivalents. Due to the fact that gallic acid is not relevant to maté (González de Mejia et al., 2005), it is more appropriate to express TPC as chlorogenic acid equivalents. In the case of tea, gallic acid is not relevant either, but in comparison to other standards which may be more relevant, (e.g., catechins such as EGCG), gallic acid is more freely available and more stable than the other standards.

The TPC in the leaf fraction resulted significantly higher than the TPC of the twig fraction $(p \leq 0.012)$. The results found in this work were $22.2 \pm 0.1 \mathrm{~g} \mathrm{CAE} \% \mathrm{dm}$ in the leaf extraction and $14.1 \pm 1.2 \mathrm{~g} \mathrm{CAE} \% \mathrm{dm}$ in the twig extraction; these values resulted higher than the values reported by Holovatty (2007) (17.3 \pm 0.3 and $6.6 \pm 0.1 \mathrm{~g} \mathrm{CAE} \% \mathrm{dm}$ in the leaves and twigs respectively). These differences may be attributed to many reasons, such as the lack of standardization in the extraction and in the Folin-Ciocalteu application.

The aqueous extract of the elaborated maté and the maté tea-bags were $36.30 \pm 2.24 \mathrm{~g} \% \mathrm{dm}$ and $40.86 \pm 1.22$ $\mathrm{g} \% \mathrm{dm}$ respectively. The soluble solids in the three maté beverages resulted $22.81 \pm 3.620,11.08 \pm 2.148$ and $37.7 \pm 0.418 \mathrm{~g} \% \mathrm{dm}$ for the Hot Mate, Cold Mate and Mate Tea-bag respectively.

The caffeine content of the elaborated maté and the maté tea-bags resulted $1.21 \pm 0.08 \mathrm{~g} \% \mathrm{dm}$ and $1.32 \pm 0.21$ $\mathrm{g} \% \mathrm{dm}$ respectively.

The TPC of the different brands and extraction procedures are presented in Table 1. The resulting ANOVA for TPC in Hot Maté, Cold Maté and Control extraction is presented in Table 2. The extraction procedure affected the TPC $(\mathrm{p} \leq 0.0001)$. The TPC in the different maté extracts decreased in the order: Maté-Tea, Control extraction, Hot Maté, Cold Maté. Many factors, such as the extraction temperature (Wettasinghe and Shahidi, 1999), the solvent polarity (Turkmen et al., 2006) and the solid-to-solvent ratio (Cacace and Mazza, 2003), may significantly influence the extraction efficacy of polyphenols. Maté tea-bag is produced almost exclusively from leaves, whereas elaborated maté is produced from leaves and twigs (usually in a $65 / 35$ proportion. The avegare percentage of each fraction of maté resulted: $76.7 \pm 2.22 \%$ for leaves, $22.7 \pm 2.42 \%$ for twigs and $0.60 \pm 0.41 \%$ for impurities.

Is important to clarify that in the case of Hot and Cold Maté, the infusion time between additions of water and consumption is comparatively short, so surely none of these beverages ensures the total extraction of maté polyphenols compounds. Currently no standard is available for total extraction of maté polyphenols thus we reffered the avegare TPC of the beverages simulated to the total soluble solids. It is well known total soluble solids represent the amounts of solid extracted in specific extraction conditions

The average TPC of the Hot Maté and the Cold Maté are presented in Table 3, they represented the $48 \%$ and $36 \%$ of the total soluble solids respectively. In Maté Tea-bag the average TPC was $19.25 \pm 0.37 \mathrm{~g} \mathrm{CAE} \mathrm{\%} \mathrm{dm}$ which represented the $50 \%$ of the total soluble solids whereas the respective TPC expressed as GAE resulted $10.52 \pm 0.25 \mathrm{~g} \mathrm{GAE} \% \mathrm{dm}$. The above result are closely to the results reported by González de Mejia et al. (2005) and Bravo et al. (2007) for mate decoctions. In those reports the TPC ranged 23.6 - 49.0 CAE \% dm and 9.0 - 17.6 g GAE \% dm (González de Mejia et al., 2005) and 9.07 - $9.90 \mathrm{~g}$ GAE \% dm (Bravo et al., 2007).

A previuos report based in polyphenols extraction mixtures (at $85{ }^{\circ} \mathrm{C}$ ) suggests that polyphenols in fresh leaves and twigs of maté are different (Pagliosa et al., 2010). In this report the better extraction from leaves was found when water was used and in the case of twigs when a methanol/water mixture (80/20 in volume) was used. 
Table 1. Total polyphenol content of different brands and extraction procedures

\begin{tabular}{|c|c|c|c|c|}
\hline & Hot Mate & Cold Mate & Mate tea-bag & Control \\
\hline Brand* & $\begin{array}{l}\text { TPC-CAE }^{\mathrm{a}} \\
(\mathrm{g} \mathrm{CAE} \% \mathrm{dm})\end{array}$ & $\begin{array}{l}\text { TPC-CAE } \\
(\mathrm{g} \mathrm{CAE} \% \mathrm{dm})\end{array}$ & $\begin{array}{l}\text { TPC-CAE } \\
(\mathrm{g} \mathrm{CAE} \mathrm{\%} \mathrm{dm)}\end{array}$ & $\begin{array}{l}\text { TPC-CAE } \\
(\mathrm{g} \mathrm{CAE} \% \mathrm{dm})\end{array}$ \\
\hline 1 & $11.72 \pm 0.12$ & $4.18 \pm 0.10$ & --- & $19.32 \pm 0.41$ \\
\hline 2 & $10.44 \pm 0.01$ & $3.24 \pm 0.06$ & --- & $15.84 \pm 0.29$ \\
\hline 3 & $9.58 \pm 0.05$ & $3.57 \pm 0.06$ & $20.10 \pm 0.20$ & $16.50 \pm 0.14$ \\
\hline 4 & $12.94 \pm 0.16$ & $4.11 \pm 0.10$ & --- & $17.10 \pm 0.63$ \\
\hline 5 & $11.06 \pm 0.01$ & $3.89 \pm 0.08$ & --- & $17.45 \pm 0.13$ \\
\hline 6 & $10.74 \pm 0.26$ & $2.56 \pm 0.04$ & $18.14 \pm 0.12$ & $16.87 \pm 0.37$ \\
\hline 7 & $11.77 \pm 0.04$ & $5.49 \pm 0.02$ & $18.61 \pm 0.15$ & $17.31 \pm 0.08$ \\
\hline 8 & $10.85 \pm 0.06$ & $5.19 \pm 0.07$ & $19.76 \pm 0.25$ & $18.24 \pm 0.10$ \\
\hline 9 & $9.16 \pm 0.10$ & $4.25 \pm 0.03$ & $19.66 \pm 0.28$ & $17.45 \pm 0.05$ \\
\hline 10 & $11.74 \pm 0.03$ & $3.83 \pm 0.08$ & --- & $17.91 \pm 0.07$ \\
\hline Brand* & $\begin{array}{l}\text { TPC-GAE }^{\mathrm{b}} \\
(\mathrm{g} \text { GAE } \% \mathrm{dm})\end{array}$ & $\begin{array}{l}\text { TPC-GAE } \\
(\mathrm{g} \text { GAE \% dm) }\end{array}$ & $\begin{array}{l}\text { TPC-GAE } \\
(\mathrm{g} \text { GAE } \% \mathrm{dm})\end{array}$ & $\begin{array}{l}\text { TPC-GAE } \\
(\mathrm{g} \text { GAE } \% \mathrm{dm})\end{array}$ \\
\hline 1 & $6.91 \pm 0.07$ & $2.51 \pm 0.06$ & --- & $10.56 \pm 0.22$ \\
\hline 2 & $6.19 \pm 0.01$ & $1.97 \pm 0.03$ & --- & $8.66 \pm 0.16$ \\
\hline 3 & $5.21 \pm 0.03$ & $1.95 \pm 0.03$ & $11.00 \pm 0.11$ & $9.02 \pm 0.08$ \\
\hline 4 & $7.60 \pm 0.09$ & $2.47 \pm 0.06$ & --- & $9.35 \pm 0.35$ \\
\hline 5 & $6.54 \pm 0.01$ & $2.34 \pm 0.05$ & --- & $9.56 \pm 0.07$ \\
\hline 6 & $5.85 \pm 0.14$ & $1.45 \pm 0.02$ & $9.91 \pm 0.07$ & $9.22 \pm 0.20$ \\
\hline 7 & $6.41 \pm 0.02$ & $3.00 \pm 0.01$ & $10.17 \pm 0.08$ & $9.46 \pm 0.05$ \\
\hline 8 & $5.91 \pm 0.04$ & $2.83 \pm 0.04$ & $10.80 \pm 0.13$ & $9.97 \pm 0.06$ \\
\hline 9 & $4.98 \pm 0.06$ & $2.38 \pm 0.02$ & $10.74 \pm 0.15$ & $9.54 \pm 0.03$ \\
\hline 10 & $6.92 \pm 0.02$ & $2.31 \pm 0.05$ & --- & $9.79 \pm 0.04$ \\
\hline
\end{tabular}

* Data are expressed as mean \pm standard error of two determinations per sample. ${ }^{\mathrm{a}}$ TPC-CAE: Total polyphenol content expressed as chlorogenic acid equivalents; ${ }^{\mathrm{b}} \mathrm{TPC}-\mathrm{GAE}$ : Total polyphenol content expressed as gallic acid equivalents.

Table 2. ANOVA analysis for total polyphenol content

\begin{tabular}{llllll}
\hline \multirow{2}{*}{ Source of variation } & & \multicolumn{2}{l}{ TPC-CAE } & \multicolumn{2}{l}{ TPC-GAE } \\
\cline { 3 - 6 } f.d. & F & p-value & F & p-value \\
\hline Model & 11 & 694.67 & $<0.0001$ & 510.27 & $<0.0001$ \\
Extraction Procedure & 2 & 2.51 & 0.0461 & 2.4 & 0.0545 \\
Brand & 9 & & & & \\
Error & 18 & & & & \\
Total & 29 & & & & \\
\hline
\end{tabular}

f.d.: degrees of freedom; TPC-CAE: Total polyphenol content expressed in mass percentage as chlorogenic acid equivalents; TPC-GAE: Total polyphenol content expressed in mass percentage as gallic acid equivalents. 
Turkmen et al. (2006), studied the effect of water and different organic solvents (acetone, ethanol and methanol at $50 \%, 80 \%$ and $100 \% \mathrm{v} / \mathrm{v}$ ) in the extraction of polyphenols and on the antioxidant capacity of several vegetables including maté. In the case of mate leaves all extracts prepared with $50 \%$ solvents showed the highest levels of polyphenols and the lowest amounts of polyphenols were obtained with $100 \%$ acetone and $100 \%$ ethanol. They concluded that the solvent polarity increases the polyphenols extraction.

The results of Tukey's Test significance for TPC from Hot Maté, Cold Maté and Control extraction are shown in Table 3 .

Table 3. Results of Tukey's Test significance for TPC

\begin{tabular}{|c|c|c|}
\hline & Mean values* & \\
\hline & TPC-CAE & TPC-GAE \\
\hline & (g \% dm) & $(\mathrm{g} \% \mathrm{dm})$ \\
\hline Hot Mate & $11.00^{\mathrm{a}}$ & $6.25^{\mathrm{a}}$ \\
\hline Cold Mate & $4.03^{\mathrm{b}}$ & $2.32^{\mathrm{b}}$ \\
\hline Control & $17.4^{\mathrm{c}}$ & $9.51^{\mathrm{c}}$ \\
\hline PC-CAE: 0.9155 & Error $_{\mathrm{TPC}-\mathrm{CAE}}: 0.6435$ & f.d.TPC-CAE $: 18 \mathrm{n}: 10$ \\
\hline $\mathrm{LSD}_{\mathrm{TPC}-\mathrm{GAE}}: 0.2542$ & Error $_{\mathrm{TPC}-\mathrm{GAE}}: 0.5753$ & f.d. TPC-GAE $: 18 \mathrm{n}: 10$ \\
\hline
\end{tabular}

*Values bearing different letters are significantly different at $\mathrm{p} \leq 0.05$. f.d.: degrees of freedom; TPC-CAE: Total polyphenol content expressed in mass percentage as chlorogenic acid equivalents; TPC-GAE: Total polyphenol content expressed in mass percentage as gallic acid equivalents.

The TPC correlated with the soluble solids in the case of Cold Maté $\left(\mathrm{r}_{\text {Pearson }}=0.96, \mathrm{p} \leq 1.5 \times 10^{-5}\right)$ and Hot Maté $\left(\mathrm{r}_{\text {Pearson }}=0.85, \mathrm{p}<0.01\right)$. TPC also correlated with the aqueous extract from maté in the case of Hot Maté, but did not correlate with the leaf percentage, probably because it is very homogeneous within all brands.

\subsection{Estimation of the Total Polyphenol Intake from Maté Beverages}

By drinking $500 \mathrm{~mL}$ (volume usually consumed) of Hot Maté and Cold Maté, the total polyphenol intake (TPI) is $5.17 \pm 0.53 \mathrm{~g} \mathrm{CAE}$ or $2.94 \pm 0.38 \mathrm{~g} \mathrm{GAE}$; and $1.89 \pm 0.40 \mathrm{~g}$ CAE or $1.09 \pm 0.21 \mathrm{~g}$ GAE respectively. These high differences between Hot and Cold Maté are probably due to the temperature used in the extraction.

For a cup $(200 \mathrm{~mL})$ of Maté Tea-bag, the TPI is $0.54 \pm 0.02 \mathrm{~g}$ CAE or $0.30 \pm 0.01 \mathrm{~g}$ GAE. In the case of Maté tea-bag, the water to solid ratio employed is 6.6 times higher than in Hot and Cold Maté.

The habit of drinking Hot Maté and Cold Maté implies the daily consumption of large volumes of these beverages: according to Castellsague et al. (2000) the heavy drinkers consume more than $1.5 \mathrm{~L} /$ day, while light drinkers consume less than $0.5 \mathrm{~L} /$ day.

The polyphenol compounds may be classified into different groups as a function of the number of phenol rings that they contain and of the structural elements that bind these rings to one another. Distinctions are thus made between the phenolic acids, flavonoids, stilbenes and lignans. In addition to this diversity, polyphenols may be associated with various carbohydrates, organic acids and lipids and with one another. As an example, chlorogenic acid is a caffeic acid ester linked to quinic acid. The structural diversity of polyphenols makes the estimation of their content in food difficult. Polyphenols concentrations in food vary according to numerous genetic, environmental and technologic factors.

A major source of polyphenols is beverages (as maté beverages, red wine, coffee and tea). Each one of these beverages contains different complex mixtures of polyphenols. Cultural and dietary habit dictates which forms of polyphenols are taken up.

In maté extracts, monocaffeoyl quinic isomers and dicaffeoyl quinic isomers had been reported. The main monocaffeoyl quinic isomers reported are chlorogenic acid (5-o-caffeoyl quinic acid), neochlorogenic acid (3-o-caffeoyl quinic acid) and cryptochlorogenic acid (4-o-caffeoyl quinic acid). The main dicaffeoyl-quinic isomers are 3,4-dicaffeoylquinic acid, 3,5-dicaffeoylquinic acid and 4,5-dicaffeoylquinic acid. According to Bravo et al. (2007), together they account for over $90 \%$ of the TPC in maté extracts, representing close of 
$10 \%$ of maté dry weight (Filip et al., 2001). Rhamnoglucose derivatives of quercetin (e.g. rutin) and kaempferol had been reported as the major flavonoids, accounting together the $90 \%$ of the flavonols present in maté extracts (Bravo et al., 2007).

The phenolic compounds in red wine are represented by flavonoids as anthocyanins (mainly malvidin-3glucoside and cyanidin), flavonols (mainly catechin and epicatechin) and flavonols (mainly quercetin); and nonflavonoids as stilbenes (mainly resveratrol) and some phenolic acids (gallic acid and caffeic acid) (Rice-Evans et al., 1996).

The polyphenol compounds in green tea are represented by the free-forms of flavan-3-ols (mainly (+)-catechin, (-)-epicatechin and (-)-epigallocatechin) and their galloylated esters (mainly, (-)-epigallocatechin gallate and (-)-epicatechin gallate)(Salah et al., 1995). During green tea production, the catechins remain relatively intact during the process. This is because the enzymes, which can catalyze their oxidative polymerization, are deactivated by heat treatment soon after plucking. Black tea production, on the other hand, involves a leaf disruption step to promote the enzymatic oxidation of the flavanols (catechins) present in the fresh green leaf to produce polymeric flavonoids (theaflavins and thearubigins) (Astill et al., 2001). Thus, the prepared green teas contain substantially higher levels of catechins than prepared black teas (Astill et al., 2001). The flavonoids dominate the composition of the brew solids in tea ( $25 \%$ on total soluble solids) and constitute nearly $86 \%$ of the TPC (Lakenbrink et al., 2000).

To facilitate comparison, the total polyphenol concentrations (TPCo) in several beverages tested are expressed as mg GAE per $100 \mathrm{~mL}$ of beverage (see Table 4). In Table 4, the great variation (expressed as standard error) is justified by the fact that the TPC of several different varieties of samples was/were averaged; e.g. five red wine varieties, ten brands of elaborated maté (industrialized by differents drying methods).

Table 4. The total polyphenol concentration in several beverages

\begin{tabular}{ll}
\hline Beverage & $\begin{array}{l}\text { TPCo* } \\
(\mathrm{mg} \mathrm{GAE} / 100 \mathrm{~mL})\end{array}$ \\
\hline Hot Mate & $586 \pm 34$ \\
Cold Mate & $220 \pm 74$ \\
Green Tea infusion & $217 \pm 14$ \\
Red wine & $198 \pm 33$ \\
Mate Tea infusion & $150 \pm 42$ \\
Black Tea infusion & $147 \pm 28$ \\
\hline
\end{tabular}

* Data are expressed as mean \pm standard error of two determinations per sample. TPCo: Total polyphenol concentration; GAE: gallic acid equivalents.

The average value for the analysed red wines was close to $2 \mathrm{~g} \mathrm{GAE} / \mathrm{L}$ and was within the ranges reported for this beverage (1.96 g GAE/L, Bravo et al., 2007; 1-4 g/L, Dreosti et al., 2000;1.85 g GAE/L, Paixão et al., 2007).

In black tea and green tea, the TPCo was higher than the concentration previously reported for these infusions (Table 5) (nearly 1.1-1.8 and 1.8-6.2 times respectively). These differences may be justified by the fact that the TPC of the tea infusions are influenced by variety, growing environment, manufacturing conditions and finally the preparation method (different brew times and temperatures, amounts of tea and water used, amount of agitation) (Astill et al., 2001). At brew times up to $2 \mathrm{~min}$, extraction of total phenolics is relatively inefficient (Lakenbrink et al., 2000). 
Table 5. Summary of some representative publications of the TPC in tea and mate tea

\begin{tabular}{|c|c|c|c|c|}
\hline & $\begin{array}{l}\text { TPC } \\
(\mathrm{mg} \mathrm{GAE} / 100 \mathrm{~mL})\end{array}$ & $\begin{array}{l}\text { WSR } \\
(\mathrm{mL} / \mathrm{g})\end{array}$ & $\begin{array}{l}\text { Brew } \\
\text { Time } \\
(\mathrm{min})\end{array}$ & References \\
\hline Green tea & $116.22 \pm 1.07$ & $100 / 1$ & 3 & BRAVO et al. (2007) \\
\hline (tea-bag) & $43.3-82.5$ & $100 / 1$ to $114 / 1$ & 3 & ASTILL et al. (2001) \\
\hline Black tea & $93.62 \pm 2.20$ & $100 / 1$ & 3 & BRAVO et al. (2007) \\
\hline (tea-bag) & $80-130$ & $75 / 1$ to $100 / 1$ & 3 & ASTILL et al. (2001) \\
\hline $\begin{array}{l}\text { Tea* } \\
\text { (loose leaves) }\end{array}$ & 35.2 & $125 / 1$ & $* *$ & $\begin{array}{l}\text { ACTIS-GORETTA et al. } \\
(2002)\end{array}$ \\
\hline $\begin{array}{l}\text { Maté tea (loose } \\
\text { leaves) }\end{array}$ & & & $* *$ & $\begin{array}{l}\text { ACTIS-GORETTA et al. } \\
(2002)\end{array}$ \\
\hline
\end{tabular}

* Not specify green or black. ${ }^{* *}$ Not specify.

\section{Conclusions}

The comparison of the total polyphenol content of several beverages provided evidence that maté beverages are rich sources of antioxidant phenolics. Among the three ways of consumption of maté, the Hot Maté provides the highest intake of total polyphenols because of several reasons: it is consumed in large volumes (around $500 \mathrm{~mL})$, is prepared with more elaborated mate $(50 \mathrm{~g})$ than the Maté tea-bag $(3 \mathrm{~g})$ and the temperature of the beverage is higher than in Cold Maté.

Among the three maté beverages, the Maté tea-bag beverage exhibited the highest extraction efficiency because the water to solid ratio employed was 6.6 times higher than in Hot and Cold Maté.

During the mate beverage simmulations, the behavior of the total soluble solids resulted similar to the total polyphenols content.

We suggest including the total polyphenol content in the Nutrition Facts of maté products as a differential attribute that surely will promote the international market.

\section{Acknowledgments}

We thank National Council of Scientific and Technical Research (CONICET) and Mate's National Institute (INYM) for the financial support of the present work and DINCYT Foundation for the use of its laboratory equipment.

\section{References}

Actis-Goretta, L., Mackenzie, G. G., Oteiza P. I., \& Fraga, C. G. (2002). Comparative study on the antioxidant capacity of wines and other plant-derived beverages. Annals of the New York Academy of Sciences, 957, 279-283.

Anesini, C., Ferraro G., \& Filip, R. (2006). Peroxidase-like activity of Ilex paraguariensis. Food Chemistry, 97(3), 459-464. http://dx.doi.org/10.1016/j.foodchem.2005.05.025

Astill, C., Birch, M. R., Dacombe, C., Humphrey P. G., \& Martin, P.T. (2001). Factors affecting the caffeine and polyphenol contents of black and green tea infusions. Journal of Agricultural and Food Chemistry, 49(11), 5340-5347. http://dx.doi.org/10.1021/jf010759+

Bravo, L., Goya L., \& Lecumberri, L. (2007). LC/MS characterization of phenolic constituents of mate (Ilex paraguariensis, St. Hil.) and its antioxidant activity compared to commonly consumed beverages. Food Research International, 40, 393-405. http://dx.doi.org/10.1016/j.foodres.2006.10.016

Cacace J., \& Mazza, G. (2003). Optimization of extraction of anthocyanins from black currants with aqueous ethanol. Journal of Food Science, 68, 240-248. http://dx.doi.org/10.1111/j.1365-2621.2003.tb14146.x

Castellsague, X., Muñoz, N., De Stefani, E., Victora, C. G., Castelletto R., \& Rolón, P. A. (2000). Influence of mate drinking, hot beverages and diet on esophageal cancer risk in South America. International Journal of Cancer, 88, 658-664. http://dx.doi.org/10.1002/1097-0215(20001115)88:4<658::AID-IJC22>3.0.CO 
Chandra, S., \& Gonzalez De Mejia, E. (2004). Polyphenolic compounds, antioxidant capacity, and quinone reductase activity of an aqueous extract of Ardisia compressa in comparison to mate (Ilex paraguariensis) and green (Camellia sinensis) teas. Journal of Agricultural and Food Chemistry, 52, 3583-3589. $\mathrm{http}: / / \mathrm{dx}$. doi.org/10.1021/jf0352632

Dreosti, I. E. (2000). Antioxidant polyphenols in tea, cocoa, and wine. Nutrition, 16, 692-694.

Dudonné, S., Vitrac, X., Coutiére,P., Woillez, M., \& Jean-Michel M' Erillon, J. M. (2009). Comparative study of antioxidant properties and total phenolic content of 30 plant extracts of industrial interest using DPPH, ABTS, FRAP, SOD, and ORAC assays. Journal of Agricultural and Food Chemistry, 57, 1768-1774. http://dx.doi.org/10.1021/jf803011r.

Dutra, Fabiana L. Goularte, Hoffmann-Ribani, Rosemary, \& Ribani, Marcelo. (2010). Determinação de compostos fenólicos por cromatografia líquida de alta eficiência isocrática durante estacionamento da erva-mate. Química Nova, 33(1), 119-123. http://dx.doi.org/10.1590/S0100-40422010000100022.

Filip, R., Lopez, P., Giberti, G., Coussio J., \& Ferraro, G. (2001). Phenolic compounds in seven Southamerican Ilex species. Fitoterapia, 72, 774-778. http://dx.doi.org/10.1016/S0367-326X(01)00331-8

Filip, R., Lotito, S., Ferraro G., \& Fraga, C. (2000). Antioxidant activity of Ilex paraguariensis and related species. Nutrition Research, 20(10), 1437-1446.

González De Mejia, E., Soo Song, Y., Ramírez-Mares, M. V., \& Kobayashi, H. (2005). Effect of yerba mate (Ilex paraguariensis) tea on topoisomerase inhibition and oral carcinoma cell proliferation. Journal of Agricultural and Food Chemistry, 53, 1966-1973. http://dx.doi.org/10.1021/jf048158g

Heck, C., Schmalko, M. E., \& Gonzalez De Mejia, E. (2008). Effect of growing and drying conditions on the phenolic composition of mate teas (Ilex paraguariensis). Journal of Agricultural and Food Chemistry, 56, 8394-8403. http://dx.doi.org/10.1021/jf801748s

Holovatty, S. E. (2007). Variación del contenido de polifenoles durante el procesamiento de yerba mate (Ilex paraguariensis). Posadas, Misiones. Thesis (Food Technology Master). Universidad Nacional de Misiones.

IRAM 20503. (1995). Argentine Institute of Standardization and Certification - Standard 20503: Yerba mate: Determination of mass loss at $103^{\circ} \mathrm{C}$.

IRAM 20510. (1995). Argentine Institute of Standardization and Certification - Standard 20510: Yerba mate: Determination of the aqueous extract.

IRAM 20512. (2003). Argentine Institute of Standardization and Certification - Standard 20512: Yerba mate: Determination of caffeine content.

IRAM 20514. (2006). Argentine Institute of Standardization and Certification - Standard 20514: Yerba mate: Determination of the twigs content.

ISO 14502. (2005). Determination of substances characteristic of green and black tea. Part 1: Content of total polyphenols in tea. Colorimetric method using Folin-Ciocalteu reagent.

ISO 1573, (1980). Tea, Determination of loss in mass at 103 degrees C.

Jaiswal, R., Sovdat, T., Vivan, F., \& Kuhnert, N. (2010). Profiling and characterization by LC-MSn of the chlorogenic acids and hydroxycinnamoylshikimate esters in maté (Ilex paraguariensis). Journal of Agricultural and Food Chemistry, 58, 5471-84. http://dx.doi.org/10.1021/jf904537z

Lakenbrink, C., Lapczynski, S., Maiwald, B., \& Engelhardt, U. H. (2000). Flavonoids and Other Polyphenols in Consumer Brews of Tea and Other Caffeinated Beverages. Journal of Agricultural and Food Chemistry, 48(7), 2848-2852. http://dx.doi.org/10.1021/jf9908042

Markowicz Bastos, D. H., Moura de Oliveira, D; Lobato Teixeira Matsumoto, R.; De Oliveira Carvalho, P; Lima Ribeiro, M. (2007). Yerba maté: Pharmacological properties, research and biotechnology. Medical and aromatic plant science and biotechnology. Global Science Books

Pagliosa, C. M., Vieira, M. A., Podestá, R., Maraschin, M., Bertello Zeni, A. L., Amante, E. R., Dias de Mello Castanho Amboni, R. (2010). Methylxantines, phenolic composition, and antioxidant activity of bark from residues from mate tree harvesting (Ilex paraguariensis A. St. Hil.). Food Chemistry, 122, 173-178. http://dx.doi.org/10.1016/j.foodchem.2010.02.040

Paixão, N., Perestrelo, R., Marques, J. C., \& Câmara, J. S. (2007). Relationship between antioxidant capacity and total phenolic content of red, rosé and white wines. Food Chemistry, 105(1), 204-214. 
http://dx.doi.org/10.1016/j.foodchem.2007.04.017

Rice-Evans, C., Miller N. J., \& Paganga, G. (1996). Structure-antioxidant activity relationships of flavonoids and phenolic acids. Free Radical Biology and Medicine, 20(7), 933-956. http://dx.doi.org/10.1016/0891-5849(95)02227-9

Salah, N., Miller, N. J., Parganga, G., Tifburg, L., Bolwell G. P., \& Rice Evan C. (1995). Polyphenolic flavanols as scavengers of aqueous phase radicals and as chain breaking antioxidant. Archives of Biochemistry and Biophysics, 322, 339-346. http://dx.doi.org/10.1006/abbi.1995.1473

Scipioni, G. P., Ferreyra, D. J., Acuña, M. G., \& Schmalko, M. E. (2010). Rebaudioside A release from matrices used in a yerba maté infusion. Journal of Food Engineering. 100, 627-633. http://dx.doi.org/10.1016/j.jfoodeng.2010.05.011

Turkmen, N., Sari F., \& Sedat Velioglu, Y. (2006). Effects of extraction solvents on concentration and antioxidant activity of black and black mate tea polyphenols determined by ferrous tartrate and Folin-Ciocalteu methods. Food Chemistry, 99, 835-841. http://dx.doi.org/10.1016/j.foodchem.2005.08.034

Wettasinghe M., \& Shahidi, F. (1999). Evening primrose meal: A source of natural antioxidants and scavenger of hydrogen peroxide and oxygen-derived free radicals. Journal of Agricultural and Food Chemistry, 47, 1801-1812. http://dx.doi.org/10.1021/jf9810416 